UDC 94(470+571)«1880/1890»

DOI: 10.24919/2519-058x.10.159179

\title{
Zinaida SVYASCHENKO
}

PhD hab. (History), Associate Professor of world history and methods of teaching, Pavlo Tychyna Uman State Pedagogical University, 28 Sadova Street, Uman, Ukraine, postal code20300(szv09@meta.ua

ORCID: http://orcid.org/0000-0001-5845-3115

ResearcherID: B-5144-2019 (http://www.researcherid.com/rid/B-5144-2019)

\section{Serhiy KORNOVENKO}

PhD hab. (History), Professor of Head of the Department of Intellectual Property and Civil Law Disciplines, Bogdan Khmelnytsky National University of Cherkasy, 81, T. Shevchenko Boulevard, Cherkasy, Ukraine, 18031 (s-kornovenko@ukr.net)

ORCID: https://orcid.org/0000-0002-6268-2321

ResearcherID: U-4291-2018 (http://www.researcherid.com/rid/U-4291-2018)

\section{Зінаӥда СВЯЩЕНКО}

доктор історичних наук, професор кафедри всесвітньої історії та методик навчання Уманського державного педагогічного університету імені Павла Тичини, вул. Садова, 28, м. Умань, Україна, 20300 (szv09@тета.иа)

\section{Сергій КОРНОВЕНКО}

доктор історичних наук, професор кафедри інтелектуальної власності та ичивільно-правових дисциилін Черкаського нащіонального університету імені Богдана Хмельницького, б-р Шевченка, 81, м. Черкаси, Україна, 18031 (s-kornovenko@ukr.net)

Бібліографічний опис статті: Svyaschenko, Z., Kornovenko, S. (2019). State protectionism in the agricultural politics of the Russian Empire of 1880-s - 1890-s. Skhidnoievropeiskyi Istorychnyi Visnyk [East European Historical Bulletin], 10, 34-42. doi: 10.24919/2519-058x.10.159179

\section{STATE PROTECTIONISM IN THE RUSSIAN EMPIRE'S AGRICULTURAL POLICY OF THE 1880s - 1890s}

Summary. The purpose of the article is to reveal the policy essence of state protectionism in the Russian Empire's agricultural policy of the 1880s - 1890s, to ascertain its conformity with the peasant mood and the requirements of time. The research methodology is based on such principles of historical knowledge as scientificity, historicism, objectivity, system analysis, etc., as well as on the application of general scientific, special historical and special source study methods. The research novelty is based on the fact that for the first time in Ukrainian historiography, on the basis of the analysis of archival documents and legislative acts, the policy essence of state protectionism in the Russian Empire's agricultural policy of the $1880 s-1890 s$, the degree of its responsibility to peasant attitudes and the time requirements are revealed.

In our opinion, the Great Reform of 1861 did not solve the agrarian question once and for all. The notion that the state task is to ensure the existence of peasants; the care of them clearly took shape in 
the reign of Alexander III. The essence of agricultural policy of the government was state protectionist concerning peasants. This led to the exclusion of the principle reflected in the peasant legislation of 1861 from the intellectual field of the Russian establishment. That is, the idea of giving peasants the civil liberties and transforming their land into a real private property gave way to the views, according to which the duty of the autocrat was the care of peasants. The land received by the peasants after the abolition of serfdom was considered by the government as a special fund. Its function was to ensure the existence of peasants as farmers. Conclusions. The strategic direction in agricultural policy of the tsarist government of the 1880s - 1890s was the idea of state protectionism concerning peasants. If, at the end of the 1870s and early 1880s, under the conditions of increasing peasant unrest, the government, to alleviate the acuity of land shortage, was forced to apply to the policy of resettlement of landless peasants on state land and provide them with loans for land purchase, then during the years of the temporary «calm» measures of a different nature were on the foreground. They are the restriction of sales and secrecy of land, the protection of public land tenure, the cessation of any attempt to mass resettlement of peasants, the restriction of crushing peasant farms. The measures that did not expand the trust fund, but fixed the existing holdings for their owners were taken. Conservative landlords saw a solution to the peasant issue in preserving patriarchal «foundations» in the village, in strengthening the power of nobles over peasants.

Key words: peasantry, agrarian question, the Russian Empire, state protectionism, agricultural policy.

\section{ДЕРЖАВНИЙ ПРОТЕКЦІОНІЗМ В АГРАРНІЙ ПОЛІТИЦІ РОСІЙСЬКОЇ ІМПЕРІЇ 1880 - 1890-х рp.}

Анотація. Мета статті - розкрити сутність політики державного протекціонізму в аграрній політиці Російської імперї 1880 - 1890-х рр., з'ясувати ї̈ відповідність селянським настроям та вимогам часу. Методологія дослідження грунтується на таких принципах історичного пізнання, як науковість, історизм, об'єктивність, системний аналіз тоще, а також на застосуванні загальнонаукових, спеціально-історичних та спеціальних джерелознавчих методів. Наукова новизна полягає у тому, щео вперше в украӥнській історіографії на основі аналізу архівних документів і законодавчих актів розкрито суть політики державного протекціонізму в аграрній політиці Російської імперії 1880 - 1890-х рр., ступінь ї̈ відповідності селянським настроям і вимогам часу.

На нашу думку, Велика реформа 1861 р. не розв'язала аграрне питання раз і назавжди. Уявлення про те, ще завданням держави є забезпечення існування селян, опіка над ними чітко оформилися за ичарювання Олександра III. Сутністю аграрної політики уряду став протекиіонізм держави стосовно селян. Це зумовило витіснення з інтелектуального поля тогочасного російського істеблішменту принципу, відображеного у селянському законодавстві 1861 p. Тобто, ідея надання селянам громадянських свобод і трансформачія отриманої ними землі у справжню приватну власність поступилася поглядам, відповідно до яких обов'язок самодержия - опіка над селянами. Земля, отримана селянами після ліквідаџї̈ кріпащтва, урядовими колами розглядалася як спеціальний фонд. Його функиія зводилася до того, щоб забезпечити існування селян як землеробів. Висновки. Стратегічним напрямом аграрної політики иарського уряду 1880 1890-х рр. стала ідея державного протекціонізму щуодо селян. Якщо в кінці 1870 - початку 1880-х рр. в умовах посилення селянських заворушень уряд змушений був для пом'якшення гостроти земельного голоду звертатися до політики переселення малоземельних селян на казенні землі й надавати їм кредит для купівлі землі, то в роки тимчасового «затишшя» на перший план поставали заходи іншого характеру - обмеження продажу $i$ застави надільної землі, охорона громадського землеволодіння, припинення будь-якої спроби масового переселення селян, обмеження дроблення селянських господарств, тобто, заходи, щуо не розширювали надільний фонд, а закріплювали наявні наділи за їх власниками. Консервативно налаштовані поміщики бачили розв'язання селянського питання у збереженні патріархальних «підвалин» на селі, в посиленні влади дворян над селянами.

Ключові слова: селянство, аграрне питання, Російська імперія, держсавний протекиіонізм, аграрна політика. 
Statement of the problem. The abolition of serfdom in the Russian Empire in 1861 became an important milestone in the socio economic and socio political life of the country, in the fate of millions of peasants, who amounted to $8 / 10$ of the population in the second half of the XIX and early XX centuries. There is no controversy in the fact that in 1861 the idea of becoming a distinctive watershed, «Rubicon» in the history of the Romanov Empire and its population was established in domestic and foreign historiography. At the same time, it would be wrong to suppose that the Great Reform of 1861 once and for all solved the agrarian question. According to our conviction, the correctness of which is confirmed by the development of political events of 1902 - 1907 and 1917 - 1921, the reform of 1861 only aggravated the agrarian question. It was transformed from purely economic into political, and in some cases, psychological. It became the alpha and omega of the internal politics of the post-reform autocracy, the cornerstone of the socio economic measures of the military and political regimes that competed for power in a revolutionary age.

Analysis of recent research. The issue outlined by us was indirectly raised in the works of domestic and foreign researchers devoted to the agricultural policy of the Russian Empire in the second half of the XIX century: Ye. Brusnikin (Brusnikin, 1964; Brusnikin, 1970), V. Leontovich (Leontovich, 1995), S. Sidelnikov (Sidelnikov, 1980), M. Simonova (Simonova, 1987), V. Tyan (Tyan, 2002), I. Verkhovtseva (Verkhovtseva, 2018), I. Kasian (Kasian, 2018) and others. At the same time, the essence of state protectionism in the agricultural policy of the Russian Empire of the 1880s - 1890s, its compliance with peasant attitudes and the requirements of time requires special study.

The purpose of the article. The authors of the article aim to reveal the policy essence of state protectionism ${ }^{1}$ in the Russian Empire's agricultural policy of the 1880s and 1990s, its conformity to peasant attitudes and the time requirements.

Statement of the basic material. The fact that the agrarian question required further reflection, new approaches to its solution became already clear in the 1880s. As V. Leontovich rightly observes, the idea that the state task is to ensure the existence of peasants, the care of them clearly took shape in the reign of Alexander III (Leontovich, 1995, p. 218). In our opinion, taking into account the peculiarities of the imperial social and political life of that time, the emperor himself had a leading role in shaping this understanding of the essence of the agrarian question. At the same time, this does not indicate that the policy of state protectionism was objectively justified, was in line with the peasant attitudes and leading European ideas of socio economic development of that time. Instead of continuing the course of subjectivization of the peasantry in the socio cultural space of the Russian Empire of the second half of the XIX century, the «preservation» of the peasantry and its maintenance in the «Procrustean bed» of the post-affluent reality were chosen.

Such an approach, the essence of which was state protectionism concerning peasants, led to the displacement of the Russian establishment principle reflected in the peasant legislation of 1861 from the intellectual field. That is, the idea of providing peasants with civil liberties and the transformation of their land into a real private property gave way to the views according to which «the king is a father, peasants are children», and therefore the duty of the autocrat was to take care of his children. However, nobody thought what to do when «children» became adults, how to regulate «caretaking», how to respond to those challenges that would take place in the adult life of «children». Probably the classic of the European

${ }^{1}$ In the classic definition, the word protectionism is derived from the Latin word protectio, which means patronage, protection. 
worldview - ancient Greek myths - did not help to wonder why Zeus took precedence over Chronos, despite such vigilant care of the latter over his children. Patriarchal Russian imperial conservatism of the second half of the XIX century was stronger than the educated Russian imperial liberalism of the first half of the XIX century.

The idea of state protectionism concerning peasants became a strategic direction in the agricultural policy of the tsarist government of the 1880s - 1890s. In particular, land received by peasants after the abolition of serfdom was considered by government as a special fund. Its function was to ensure the existence of peasants as farmers. This approach to the agenda raised another issue - the legal guarantee of the special fund existence, as well as an even distribution of it among the peasants. In this way, the special nature of the peasant property relations deepened, which resulted in the strengthening of the peasantry separation from other social strata of the Russian Empire.

The above-mentioned tendency has been reflected at the legislative level. First of all, its consolidation was governed by the laws of $1886,1889,1893$. Thus, the law of 18 March 1886 On the Procedure for the Resolution of Family Reparations ... (Polnoe Sobranie Zakonov Rossiyskoy Imperii, 1886-1888, pp. 116-117, No. 5578) placed barriers for the division of the home property among the members of the courtyard. The fact is that after the abolition of serfdom, the disintegration of the peasant family was intensified, due to both socio economic and subjective factors. Family divisions in the early 1880 s became a mass phenomenon. During this period, their number reached 150 thousand per year. As a condition of family division, the law of 1886 established the permission of parents or an elder family member, as well as the decision of the village meeting adopted by two-thirds of the vote. The purpose of this law was the enslavement of the «working-class family» and the subordination of all members to the «rule of the senior member». In practice, this led to the reverse effect. Divisions began to take place illegally. For example, in Buzulutskyi district they accounted for $98 \%$ of the total number of divisions (Tyan, 2002, p. 136).

Facts show that peasant family divisions continued to occur massively also after the publication of the law of 1886. In four governorates (provinces): Arkhangelsk, Vitebsk, Penza and Yaroslavl, - the total number of family divisions not only did not decrease, but increased from 2,235 in 1886 to 2,965 in 1894 (Brusnikin, 1970, p. 38). Among the governorate meetings established in 1894 to prepare a revision of the peasant legislation, only seven of them reported that in recent years, the number of family divisions had «slightly diminished» (Svod zaklyucheniy gubernskikh soveshchaniy, 1897, p. 198, 202, 211, 212, 227, 259, 260). 22 meetings came to a conclusion that the law of 18 March did not significantly affect the life of the village («it did not get accustomed in practice», «it appeared as a dead letter», and «it did not have noticeable influence») (Svod zaklyucheniy gubernskikh soveshchaniy, 1897, p. 198-261). This is evidenced by the Committees on the Needs of the Agricultural Industry (Strakhovskiy, 1904, p. 120).

N. Brzheskiy, a well-known Russian economist, reported that the law operated in different ways in governorates. For example, in Kazan Governorate, the number of family divisions constantly increased, in the Simbirsk Governorate during 1893 - 1894, according to the law, 1,172 divisions were carried out, and unauthorized ones - 1,778 (Brzheskiy, 1902 , p. 143). In the area of chernozem steppe governorates, as the author noted, the law of 18 March 1886 did not have a noticeable effect on the number reduction of family divisions (Brzheskiy, 1902, p. 143).

The press also noted the ineffectiveness of measures taken by the government. «Citizen» wrote that the law «...passed completely without a trace for a county life. They are dividing 
in the same way as before the promulgation of the law» (Grazhdanin, 1889). Governorate meetings pointed to the inactivity of village meetings, which were supposed to become a restraining factor in family divisions. The discussion of these issues by village communities turned into a purely formal act: they only authorized the divisions that actually took place. One of the zemstvo (an institution of local government) chiefs who knew the «mechanics» of this whole affair, reported, «When a father with his son or two brothers come to the starshyna or the zemstvo chief for division permission, you should know that they have already been divided, that is, they prayed to God and eat bread individually. Neither excuses, nor administrative penalties will no longer connect them into one family» (O nekotorykh merakh, 1894, p. 48).

This situation in the countryside forced Alexander III to agree reviewing the legislation regarding peasants. Under the law of 12 June 1886 (Polnoe Sobranie Zakonov Rossiyskoy Imperii, 1886-1888, pp. 303-304, No. 3807), the landlords were entitled to demand the return of workers who left them, to carry out deductions from their wages without a court. It concerned not only the shortcomings in the work or the material damage, but also actions of a personal nature: for «brutality», «disobedience», etc. In case of disobedience or «voluntary» leaving, the worker could be arrested, although the arrest was not usually used in civil cases. A striking example of the conservative nature of autocracy policy was the resettlement law of 13 July 1889 (Polnoe Sobranie Zakonov Rossiyskoy Imperii, 1889-1891, pp. 535-538, No. 6198). The question of the right and terms of resettlement should, in each case, be considered by the ministers of internal affairs and state property. "Voluntary» settlers were to be detained and returned to their old place of residence (Brusnikin, 1970, p. 37).

In this cycle of autocratic legislation concerning peasants, the law of 1889 on the introduction of zemstvo chiefs (Polnoe Sobranie Zakonov Rossiyskoy Imperii, 1889-1891, No. 6196) was distinguished. Its content was aimed at weakening the basic importance of the reform of the $1860 \mathrm{~s}$ - the abolition of serfdom - and returning to the time when peasant relations were fully regulated by the votchyna (land estate that could be inherited) police authorities of the landlords. Having restored feudal ordinances, the new law completely subordinated to the zemstvo chief of peasant self-government. In accordance with the Regulations of 1889, only a hereditary nobleman could be the zemstvo chief; the post of the zemstvo chief combined administrative and judicial power. The zemstvo chief could bring any question to the meeting for consideration and suspend any decision of this meeting, passing it to the «powiat (county) congress», most part of which included the same zemstvo chiefs. All officials of the village and the volost (a traditional administrative subdivision) were subordinated to the zemstvo chief. He asserted them on their posts, they could be fined by him, and he could arrest and dismiss them from performing official duties. The posts of the peace judges in the county were canceled, the cases were considered by the peasant district court. A volost judge was appointed by the zemstvo chief from the candidates proposed to him by the village meetings; In addition, the zemstvo chief could suspend any verdict of the volost court.

The right of the zemstvo chief to impose a fine on peasants of up to 6 rubles, and arrest them for up to 3 days (officials of peasant self-government - up to 5 rubles and 7 days) was economically, legally, and morally unacceptable for peasants. Under this law, the zemstvo chiefs under the threat of fines committed any self-government: forced the peasants to lie about themselves, arrested the meeting participants who did not vote for favorable proposals, and so on. The personality of peasants was entirely given into the disposal of the zemstvo chief (Tyan, 2002, p. 138). 
In the early $1890 \mathrm{~s}$, worried about the disadvantages of providing food for the population, which negatively affected bread trade, the government made a number of decisions to remedy the situation. Among the agrarian laws of this period, we should pay attention to the law of 8 June 1893 Rules on Land Reparations in the Community (Complete Set of Works, 1897, No. 9754) and the law of 14 December 1893 On Certain Measures to Prevent Alienation of Peasant Allotment (O nekotorykh merakh, 1898), which complicated the procedure of redistribution of public land, made it impossible to sell.

In the book Non-Harvest and People's Distress written by the director of the Department of Fiscal Assembly A. Yermolov, in the opinion of Ye. Brusnikin (Brusnikin, 1964, p. 345-374) and M. Symonova (Simonova, 1987, p. 16), the main reason for the difficult socio economic situation of the peasants was called the systematic redistribution of public land (Yermolov, 1892, p. 103). A number of high-ranking state officials considered the same. As an example could be the state secretary A. Polovtsov who wrote in his diary, «If everyone was sure that he was the full owner of the possessed land he would otherwise have worked on it and get other results» (Dnevnik gosudarstvennogo sekretarya, 1966, p. 402). A. Polovtsov noted that the chairman of the Committee of Ministers N. Bunge, who until an appointment to the civil service, was working for a while as a Professor of Political Economy at the University of Kyiv, held the same position (Dnevnik gosudarstvennogo sekretarya, 1966, p. 385). Representatives of the local administration also often called the spontaneous redistribution of the public land as the causes of peasant poverty (Russian State Historical Archive-RSHA, f. 1284, d. 70, c. 362, p. 14).

The Ministry of Internal Affairs in 1892 prepared rules that allowed land redistribution in communities. According to them, the redistribution of land in the communities could only be carried out subject to the decision of the $2 / 3$ of the village meeting. The peasants had to know the time for land redistribution in advance, but not more than once every 12 years. The decision of the village meeting was approved only after it was considered by the powiat congress of the zemstvo chiefs. S. Witte, who held the post of Minister of Finance at that time, introduced a proposal to the bill, according to which the landlord who added fertilizers to the land had the right to retain his share or receive compensation for the loss of future profits.

Initially, the bill was approved by the State Council, and the project became the law after being signed on 8 June 1893 by the king (Polnoe Sobranie Zakonov Rossiyskoy Imperii, 1893 - 1897, No. 9754). In real life, this document only complicated the relations between members of the community; therefore no significant improvements for peasants occurred. The authorities were interested in community preserving. At the same time, according to the law, community involvement in the economic activity of individual peasants was limited, which led to the establishment of household land tenure.

In the same context, we should draw our attention to the law of 14 December 1893, known as On Some Measures to Prevent the Alienation of Peasant Lands (O nekotorykh merakh, 1898, p. 240). During its preparation, in the accompanying note of the elaborated draft of the bill, Minister of Internal Affairs I. Durnovo stressed the importance of a new law for preventing the peasants land dispossess (RSHA, f. 1405, d. 11, c. 77, p. 42). In our opinion, it is difficult to agree with such judgments. In accordance with the law, it was impossible to secure a pledge of land in banks, and the sale of land allotments was allowed only by fellow villagers. The content of Article 94 is clearly evidenced by these innovations, «Plots of allotments bought by individual peasants or those which are in hereditary use, may be alienated ... only to persons assigned to village communities». In this way, the home and family areas were equated with their legal status to those purchased by the peasants in their property. 
By 1893 , at the request of a landlord who had made a ransom beforehand, the community was obliged to allocate the relevant plot or to pay the money. Such a peasant remained a member of the community, but could also leave it by selling the plot. The law of 14 December 1893 greatly limited the right of the community to dispose of land. It was possible to redeem the land allotments only if there was consent to this of the $2 / 3$ of the village meeting, and its decision was necessarily to be approved by the powiat congress of the zemstvo chiefs (O nekotorykh merakh, 1898, p. 241). According to this document, the peasants were deprived of the land allotments ownership «promised to them»; they could not freely dispose of the plots. The peasants were taken out of the sphere of civil law, according to which nobody could take part in the general possession of common property against the will (Svod zakonov grazhdanskikh, 1912, p. 550). However, from the standpoint of civil law, the legal status of allotments was very uncertain. In connection with the redemption debt (until 1907), the land was in a pledge from the state, the subject of rights to land was a village community; the lands of peasants, intermingled in the household and community village, had no fixed and documented borders (Khristoforov, 2011, p. 37).

I. Verkhovtseva believes that by these laws, the government essentially institutionalized the land ownership of village communities as a collective one and provided organizational and legal support to these communities, in the first instance to ensure the implementation of fiscal tasks and redemption payments in the village by its residents. The strengthening of self-organization in the village on the basis of self-government and subjectivization of village communities became the consequences of that (Verkhovtseva, 2018, p. 18).

Thus, in this way, the state tried to keep the multimillion masses of the rural population free of power even in terms of their property; tsarism and the nobility, implementing the state protectionism policy against the peasants, did their utmost to curb the development of commodity-money relations in the village.

However, the peasants found a variety of ways to bypass their imposed laws that did not meet the economic needs of the time. For example, there are known cases of concluding socalled «assignment» agreements. According to them, the «assignment» of land for monetary remuneration was carried out according to household records, compiled on ordinary or stamp paper in the presence of witnesses; sometimes the stamp of village elderly was affixed, sometimes the agreement was certified contrary to the law of the village government (Selikhov, 2002, p. 93). Such agreements were concluded by settlers in Siberia very often, although in many cases the land liberated by the settlers was bought by wealthy peasants. At the same time, landless people did not have anything to evict from their fellow villagers (RSHA, f. 1273 , d. 1 , c. 437 , p.11).

Current official statistics indicate that the number of land sold after the adoption of the law of 14 December 1893 and a number of measures by the government to restrict the sale of landed estates increased. Thus, if during 1883 - 1892 in Ukraine land market received 82,930 dessiatyns of land, then in the next decade $(1893-1902)$ by $45.8 \%$ more $-120,961$ dessiatyns. Most of the land was sold in the Right-Bank Ukraine, where land trade increased by $77.6 \%$ over the relevant period. Accordingly, in Southern Ukraine - by $71.6 \%$, on the Left Bank - by 39.5\% (Materialy po statistike dvizheniya zemlevladeniya v Rossii, 1902, table $1,2,4)$. Consequently, despite the anti-market laws adopted by the conservatives, land trade was increasing.

Conclusions. Thus, the idea of state protectionism concerning peasants was the strategic direction in the agricultural policy of the tsarist government of the $1880 \mathrm{~s}-1890 \mathrm{~s}$. If, at the end 
of the 1870 s and early 1880 s, under the conditions of increasing peasant unrest, the government, to alleviate the acuity of land shortage, was forced to apply to the policy of resettlement of landless peasants on state land and provide them with loans for land purchase, then during the years of the temporary «calm» measures of a different nature were on the foreground. They are the restriction of sales and secrecy of land, the protection of public land tenure, the cessation of any attempt to mass resettlement of peasants, the restriction of crushing peasant farms. The measures that did not expand the trust fund, but fixed the existing holdings for their owners were taken. Conservative landlords saw a solution to the peasant issue in preserving patriarchal «foundations» in the village, in strengthening the power of nobles over peasants. In fact, the policy of state protectionism contradicted the general economic, modernization processes that took place in the country, led to the transformation of the agrarian question from a purely socio economic to a socio political problem. In future it became the cause of the peasant revolution of 1902 and eventually led to the fall of the Romanov Empire.

The peasant-related subject is quite promising, as it is noted by Ukrainian researchers (Prysiazhniuk, 2018). The problem proposed in the article, considering that the regulation of agrarian legislation is relevant to modern Ukraine, needs further development at macro and micro levels through the use of new documentary sources and narratives.

Acknowledgments. Sincere thanks to the rector of the Uman State Pedagogical University Paul Tychiny Alexander Bezludniy.

Funding. The author received no financial support for the research, authorship, and/or publication of this article.

\section{BIBLIOGRAPHY}

Brusnikin, Ye. M. (1970). Krestyanskiy vopros v Rossii v period politicheskoy reaktsii (86 90 -e gody XIX veka) [The peasant question in Russia in the period of political reaction $(86-90 \mathrm{~s}$ of the XIX century)]. Voprosy istorii, 2, 34-47. [in Russian].

Brusnikin, Ye. M. (1964). Podgotovka zakona 14 dekabrya 1893g. o neotchuzhdaemosti krestyanskikh nadelnykh zemel [Preparation of the law of December 14, 1893. about the inalienability of peasant allotment lands]. Uchenye zapiski Gorkovskogo gos. un-ta. Ser. ist.-filol, 1 (72), 345-374. [in Russian].

Brzheskiy, N. K. (1902). Ocherki yuridicheskogo byta krestyan [Essays on the legal life of the peasants]. Sankt-Peterburg: Tipografiya V. Kirshbauma. Retrieved from https://books.google.com.ua/ books?id [in Russian].

Dnevnik gosudarstvennogo sekretarya A.A. Polovtsova (1966). [Diary of State Secretary A.A. Polovtsov]. (Vol. 2). Moskva: Nauka, 596 p. [in Russian].

Grazhdanin [Citizen]. (1889). № 56. [in Russian].

Kasian, A. I. (2018). Volosni skhody Pravoberezhnoi Ukrainy v poreformenyi period [Volost assemblies in Right-bank Ukraine during the post-reform period]. Ukrainskyi selianyn,19, 36-39. doi:10.31651/2413-8142-2018-19-36-40 [in Ukrainian].

Khristoforov, I. A. (2011). Ot Speranskogo do Stolypina: krestyanskaya reforma i problema zemleustroystva [From Speransky to Stolypin: peasant reform and the problem of land management.]. Rossiyskaya istoriya, 4, 27-43. [in Russian].

Leontovich, V. V. (1995). Istoriya liberalizma $v$ Rossii $1762-1914$ [The history of liberalism in Russia during 1762 - 1914]. Moskva: Russkiy put, Poligrafresursy, 550 p. [in Russian].

Materialy po statistike dvizheniya zemlevladeniya v Rossii (1907). [Materials on statistics of land tenure movement in Russia]. Vyp. III: Pogubernskie zemelnye tseny za 40-letie. 1863 - 1902. SPb., 24 tablitsy. [in Russian].

Novikov, A. (1899). Zapiski zemskogo nachalnika [Notes of the zemstvo chief]. Sankt-Peterburg: Tip. M. M. Stasyulevicha, 240 p. [in Russian]. 
O nekotorykh merakh k preduprezhdeniyu otchuzhdeniya krestyanskikh nadelnykh zemel. (1898). [On some measures to prevent the alienation of peasant allotment lands]. Sobranie uzakoneniy $i$ rasporyazheniy pravitelstva. Izdavaemoe pri pravitelstvuyushchem senate, 28 yanvarya, 15. 238-242. [in Russian].

Polnoe Sobranie Zakonov Rossiyskoy Imperii. Sobranie trete. (1889 - 1891). [The complete collection of the laws of the Russian Empire. The third complete]. (Vol. 9 i Dopolneniya). SanktPeterburg. [in Russian].

Polnoe Sobranie Zakonov Rossiyskoy Imperii. Sobranie trete. (1886-1888). [The collection of the laws of the Russian Empire. The third complete]. (Vol. 6 i Dopolneniya). Sankt-Peterburg. [in Russian].

Polnoe Sobranie Zakonov Rossiyskoy Imperii. Sobranie trete. (1893 - 1897). [The complete collection of the laws of the Russian Empire. The third complete]. Vol. 13 i Dopolneniya. SanktPeterburg. [in Russian].

Prysiazhniuk, Yu. (2018). Perspektyvy selianoznavstva yak sfery doslidzhen suchasnoi ukrainskoi istoriohrafii [Prospects of peasant studies as areas of research of modern ukrainian historiography]. Skhidnoievropeiskyi istorychnyi visnyk, 6, 187-193. doi: https://doi.org/10.24919/2519-058x.8.143300 [in Ukrainian].

Rossiyskiy gosudarstvennyy istoricheskiy arkhiv (RSHA - Russian State Historical Archive).

Selikhov, D. A. (2002). Ahrarne zakonodavstvo tsarskoi Rosii v Ukraini epokhy kapitalizmu (II pol. XIX-poch. XX st.) [The agrarian legislation of tsarist Russia in Ukraine in the era of capitalism (second half of the 19th and early 20th centuries)]: (Candidate's thesis). Kharkiv, 210 s. [in Ukrainian].

Sidelnikov, S. M. (1980). Agrarnaya politika samoderzhaviya v period imperializma [Agrarian policy of autocracy in the period of imperialism]. Moskva: Izd-vo Moskovskogo un-ta, 289 p. [in Russian].

Simonova, M. S. (1987). Krizis agrarnoy politiki tsarizma nakanune pervoy rossiyskoy revolyutsii [The crisis of the tsarist agrarian policy on the eve of the first Russian revolution]. Moskva: Nauka, 254 p. [in Russian].

Strakhovskiy, I. M. (1904) Krestyanskiy vopros [Peasant question]. Nuzhdy derevni po rabotam komitetov o nuzhdakh selskokhozyaystvennoy promyshlennosti. (Vol. 1, pp. 98-150). Sankt-Peterburg. [in Russian].

Svod zaklyucheniy gubernskikh soveshchaniy po voprosam, otnosyashchimsya $k$ peresmotru zakonodatelstva o krestyanakh (1897). [Summary of Conclusions of Provincial Meetings on Issues Related to the Revision of the Law on Peasants]. (V. 2). Sankt-Peterburg. 289 p. [in Russian].

Svod zakonov grazhdanskikh [Code of Civil Law] (1912). Svod zakonov Rossiyskoy imperii. (Vol. 10 (1)). Sankt-Peterburg, 1022 p. [in Russian].

Tyan, V. V. (2002). Rossiya na izlome vekov: samoderzhavnyy rezhim na vesakh sistemnykh krizisov (vtoraya polovina XIX-nachalo XX vekov). [Russia at the turn of the centuries: the autocratic regime on the scales of systemic crises (the second half of the 19th - the beginning of the 20th centuries)]. Monografiya. Moskva: Ekslibris-Press, 368 p. [in Russian].

Verkhovtseva, I. H. (2018). Povstali hromady: samovriaduvannia selian u Rosiiskii imperii v umovakh suspilno-politychnykh potriasin pochatku XX st. [Continued communities: the peasant selfgovernment in the Russian empire in the conditions in the social-political strategies of the beginning of the XX centuries]. Ukrainskyi selianyn, 19, 18-27. doi:10.31651/2413-8142-2018-19-18-27 [in Ukrainian].

Yermolov, A. S. (1892). Neurozhay i narodnoe bedstvie [Crop failure and national disaster]. Sankt-Peterburg: Tipografiya V. Kirshbauma, 270 p. [in Russian].

The article was received on January 11, 2019. Article was recommended for publishing 02.03.2019 